\title{
EDUKASI PENGGUNAAN MEDIA SOSIAL BAGI SISWA JENJANG SEKOLAH MENENGAH ATAS DI CIREBON
}

\author{
Elvi Citraresmana, Erlina Zulkifli Mahmud, Rima Febriani, Susiyanti Rusyan \\ Fakultas Ilmu Budaya,Universitas Padjadjaran \\ E-mail: elvi.citraresmana@unpad.ac.id
}

\begin{abstract}
ABSTRAK. Kemajuan teknologi saat ini berdampak salah satunya terhadap perkembangan teknologi akses komunikasi. Sebagaimana yang diketahui, saat ini akses komunikasi semakin maju dengan pesat. Kemajuan teknologi komunikasi tersebut memberikan kemudahan bagi manusia untuk bersosialisasi antar satu sama lain. Kemudahan tersebut ditawarkan melalui munculnya banyak media sosial yang dapat digunakan oleh semua orang dari berbagai kalangan usia untuk saling berinteraksi. Lebih dari itu, masyarakat banyak yang mengakses media sosial hanya untuk sekedar mencari hiburan. Menghadapi gejala banjirnya informasi melalui media sosial tersebut yang dikhawatirkan akan berdampak terhadap sikap perilaku berbahasa masyarakat yang tidak diharapkan, kami berupaya untuk memberikan pelatihan edukasi penggunaan media sosial dengan mengamati dari gejala bahasa yang muncul. Hasil kegiatan menunjukkan bahwa siswa setelah diberikan simulasi dan pemaparan materi lebih dapat memahami dan membedakan antara berita bohong dan berita benar.
\end{abstract}

Kata kunci: kemajuan teknologi; perkembangan informasi; media sosial; kosa kata

ABSTRACT. The advancement of technology may rise to the development of information to be accessed. As we all know that the information is accessible world wide. People still could do their social life through the advancement of technology by using social media. The society more often use this social media as their self-entertainment media. This media could cause to the flooded of information without any filter. This phenomena triggered us to do the workshop of how to educate Senior High School students to use the social media, how to differentiate which the information is reliable or not through analyzing the vocabulary of language. We gave them the questionnaire first and conducted the pre-test, gave them the simulation, and finally gave them the post-test. Through the series of activities, we can conclude that these students couldn't differentiate the true information from the false one. After being treated, they eventually could differentiate the true information from the false one by identifying the vocabularies that we educated them. The general results show the promising outcomes, eventhough not $100 \%$ of the students do understand or identify the false information.

Key words: advancement of technology; development information; social media; vocabularies

\section{PENDAHULUAN}

Kemajuan teknologi komunikasi nyatanya selain memberikan dampak positif, juga memberikan dampak negatif, khususnya bagi remaja. Dunia maya berisi berita dan informasi yang tak terhitung jumlahnya. Berbagaimediasosial, diantaranyaberupa jejaring interaksi seperti Facebook, Instagram, dan Twitter; dan portal berita seputar politik, ekonomi, budaya, pendidikan seperti detik.com, viva.com, dan tempo.co; serta ada pula laman daring (website) yang berisi hiburan seperti berita selebritas (infotainment) dan gaya hidup. Keberlimpahan informasi dan literasi tersebut akan sangat membantu bila dapat dimanfaatkan dengan baik, seperti membantu remaja untuk mengaktualisasikan diri, membantu proses belajar, berinteraksi dengan teman, bermain game, atau untuk sekedar mengisi waktu luang. Akan tetapi, media sosial yang kini semakin menjamur, keberlimpahan informasi, berita dan bahan bacaan lainnya turut juga memberikan dampak buruk. Penyebaran hoaks (berarti berita bohong dalam KBBI, 2019), penipuan melalui media sosial, tindakan kriminalyang dipicu oleh penggunaan media sosial, dan penyebaran paham sesat, hal-hal tersebut merupakan dampak negatif atas kemajuan teknologi yang terus mengancam remaja selama kemajuan teknologi tersebut masih terus berkembang.

Dampak negatif akan kemajuan teknologi tidak dapat ditolak, namun dapat dicegah. Oleh sebab itu pengetahuan tentang literasi media sosial sangat penting. Hal ini yang mendasari kegiatan ini dilakukan. Tujuan yang diharapkan dari penelitian ini adalah filter terhadap konten media sosial memuat ideologi global yang tidak sesuai dengan nilai-nilai dan budaya Indonesia yang berpotensi menimbulkan disintegrasi bangsa. Sesuai dengan latar belakang bidang ilmu tim peneliti maka penelitian ini dilakukan dengan menggunakan pendekatan linguistik. Dengan filter tersebut, remaja khususnya usia Sekolah Menengah Atas (SMA) dapat lebih waspada dalam memilah berita, di antaranya mengidentifikasi berita hoaks. Dengan demikian, konten yang dapat membuat disintegrasi bangsa tidak dapat mempengaruhi sikap generasi muda Indonesia terhadap keutuhan bangsa.

Adapun pengertian literasi media itu sendiri sebagaimana yang dijabarkan oleh Considine (1995) dan Yusuf (2018) yaitu sebuah upaya perluasan informasi dan keahlian berkomunikasi yang responsif terhadap perubahan zaman, terutama perubahan yang demikian cepat pada sektor informasi dan 
media sebagai pembawa pesan informasinya (dalam Erwina dan Rezeki, 2018). Jadi, literasi media itu dapat diartikan sebagai kemampuan seseorang untuk mengakses, menganalisis, mengevaluasi, dan mengkomunikasikan informasi yang didapatkannya dalam berbagai bentuk informasi, termasuk salah satunya dalam bentuk digital yang tersedia berlimpah ruah di internet.

Setelah memahami pengertian literasi informasi di atas, jelas bahwa kemampuan literasi media tentu saja dibutuhkan mengingat saat ini terdapat banyak hoaks yang tersebar luas di berbagai macam platform media sosial di internet. Hoaks atau berita bohong didefinisikan sebagai to trick into believing or accepting as genuine something false and often preposterous '(berita bohong) yang diciptakan untuk menipu (pembacanya) agar (mereka) mempercayainya atau menerimanya sebagai suatu kebenaran dan berita ini seringkali bersifat tidak masuk akal' (Kamus Merriam Webster, 2018). Dengan demikian, hoaks pada dasarnya merupakan informasi yang direkayasa sedemikian rupa dengan tujuan tertentu, misalnya untuk mencemarkan nama baik seseorang atau untuk menutupi atau membiaskan informasi yang sebenarnya. Indonesia Mendidik (2016) menandai hoaks saat ini digunakan dengan efektif sebagai salah satu alat black campaign dalam penyelenggaraan pesta demokrasi guna mempengaruhi persepsi pemilih.

Terlebih lagi, pemilihan umum baik itu pemilihan Kepala Daerah maupun pemilihan Kepala Negara (Presiden) seringkali diwarnai dengan isu-isu politik baik isu politik yang membangun maupun isu politik yang menjatuhkan. Di era Orde Baru dalam hal pemilihan Presiden, isu politik mencuat ke permukaan dengan cara lebih halus bahkan hampir bias dan tidak terlalu kentara. Hal ini disebabkan pada era tersebut lalu lintas informasi masih terbatas. Berbeda halnya dengan yang terjadi baru-baru ini. Akun media sosial menjadi media yang dianggap efektif untuk menyampaikan perasaan individu atau golongan tertentu terhadap masalah-masalah baik sosial maupun politik di negara ini. Informasi yang digulirkan kemudian berbelok menjadi lebih banyak memuat opini pribadi dan/atau golongan dibandingkan isi informasi tersebut.

Hal tersebut dapat menimbulkan bias informasi dan mengarah kepada pembunuhan karakter karena dianggap mencemarkan nama baik. Hal pencemaran nama baik nampaknya belum sepenuhnya dipahami oleh masyarakat meskipun Undang-Undang Informasi dan Transaksi Elektronik (disingkat UU ITE) nomor 11 tahun 2018 sudah digulirkan oleh pemerintah.

Berdasarkan latar belakang yang telah disampaikan di atas, kami tim Pengabdian Pada
Masyarakat melakukan penelitian terhadap siswa di tiga Sekolah Menengah Atas/Sederajat di Cirebon. Adapun pemilihan sekolah ditentukan dengan mempertimbangkan letaknya, yaitu (a) sekolah di pusat kota; SMAN 1 Cirebon, (b) sekolah di daerah perbatasan; SMAN 1 Palimanan, dan (c) sekolah di desa; SMK Dinamika Arjawinangun. Penelitian dilakukan juga sekaligus dengan melakukan workshop literasi media dan literasi informasi kepada siswa kelas XII. Workshop sekaligus dilakukan mengingat pentingnya para siswa ini dibekali pengetahuan terhadap informasi yang mereka dapatkan setiap harinya.

Pelatihan serupa juga dilakukan olehArifin, dkk. dengan memberikan pelatihan kepada siswa di salah satu SMA di Rancaekek Kabupaten Bandung dan di salah satu SMA swasta di Kabupatan Pangandaran. Tujuan kegiatan mereka adalah untuk memberikan pemahaman yang utuh dan benar kepada siswa SMA tersebut dalam menggunakan hak kebebasan berekspresi secara bertanggung jawab (dalam Jurnal Pengabdian Pada Masyarakat Vol. 1, No. 5, Oktober 2017: 332 - 337).

\section{METODE}

Penelitian ini dilakukan dengan menggunakan metode deskriptif. Adapun tahapan pelaksanaan kegiatan dijelaskan sebagai berikut.

1. Persiapan, yaitu menentukan titik pengambilan data, dalam hal ini adalah sekolah, dengan mempertimbangkan lokasi dan kemungkinan penelitian dapat dilakukan atau tidak.

2. Survei awal, yaitu melakukan kunjungan pertama ke sekolah yang telah ditentukan untuk melihat kemungkinan pelaksanaan kegiatan di sekolah terkait dan prosedur perizinan yang harus dilakukan serta penjadwalan waktu pelaksanaan kegiatan.

3. Observasi, yaitu melakukan pengambilan data di lapangan (di sekolah yang sudah ditentukan) dan menelususi lebih dalam mengenai upaya yang sudah dilakukan oleh pihak sekolah dalam membekali para siswanya dengan kemampuan literasi media. Pengambilan data dilakukan melalui sesi pre-test dan post-test pada saat sebelum dan sesudah pemberian materi. Adapun data yang diambil berupa tes pemahaman siswa terhadap hoaks yang diambil dari sumber dalam internet.

4. Seminar/Pelatihan, yaitu kegiatan pemberian materi dasar pengenalan literasi informasi dan literasi media yang dilanjutkan dengan diskusi.

5. Evaluasi, yaitu guna mengukur pemahaman siswa setelah mengikuti seminar dan pelatihan yang diberikan. 


\section{HASIL DAN PEMBAHASAN}

Pelaksanaan tahap pertama yaitu melakukan survei ke sekolah sebagaimana yang telah ditentukan sebelumnya. Pada kegiatan survei tersebut, ditemukan bahwa pemberian materi seputar literasi informasi di SMAN 1 Palimanan dan SMK Dina-mika Arjawinangun belum dilakukan dengan optimal. Pemberian materi literasi informasi dilakukan di SMAN 1 Palimanan dilakukan hanya pada saat pelaksanaan Masa Orientasi Siswa (MOS) pada saat siswa pertama kali masuk ke sekolah. Begitu juga dengan SMK Dinamika Arjawinangun, dengan tambahan bahwa sekolah ini masih belum memiliki fasilitas perpustakaan yang memadai; ruang perpustakaan sangat kecil dengan jumlah koleksi buku yang sangat terbatas. Sementara untuk SMAN 1 Cirebon, pengenalan literasi informasi sudah dilakukan dengan cukup efektif. Hal tersebut terlihat dari adanya program sekolah yang menciptakan pojok literasi, yaitu rak berisi buku-buku yang ditempatkan di sudut-sudut strategis di sekolah, seperti di taman, di sudut kelas, dan di lobby sekolah. Adapun koleksi yang disimpan beragam, mulai dari buku-buku pengetahuan, majalah, dan juga yang menarik yaitu adanya kliping-kliping yang dibuat oleh para siswa (hasil tugas sekolah).

Tahap selanjutnya yaitu pemberian materi kepada para siswa di masing-masing sekolah. Terdapat dua materi yang diberikan, yaitu (1) pengenalan literasi informasi dan (2) pengenalan literasi digital-sosial media. Pada materi pengenalan literasi informasi, para siswa diberikan pemahaman bahwa literasi informasi merupakan kemampuan seseoranguntukmencari,menemukan, mengevaluasi, dan menggunakan informasi dari berbagai sumber. Siswa juga dihimbau untuk memiliki kemampuan literasi informasi guna menghindari termakan hoaks atau terjebak dampak negatif dari keberadaan internet. Sebagaimana yang diketahui, bahwa saat ini pengambilan keputusan dipertimbangkan sebelumnya dengan mengakses informasi dengan menggunakan internet. Adapun pengambilan keputusan yang dimaksud sangat beragam, mulai dari hal kecil misalnya mau makan apa dan di mana, mau beli telepon genggam (handphone) model apa dan berapa harganya, sampai hal yang besar misalnya mau melanjutkan studi (pendidikan kuliah) di mana. Dengan begitu, tentu saja kemampuan literasi informasi sangat dibutuhkan untuk menghindari cybercrime atau kejahatan dunia maya, di antaranya penipuan.

Selain itu, siswa juga diberikan pemahaman akan beragam kemasan/format informasi. Format informasi dirumuskan ke dalam dua jenis berikut ini.

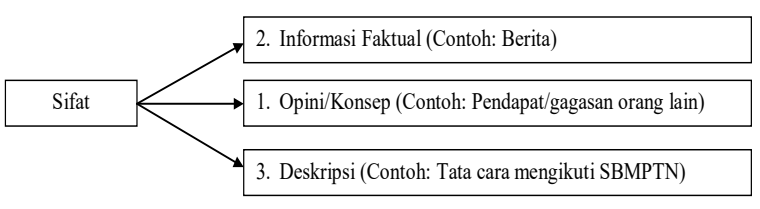

sumber: penulis

Gambar 1. Ragam/Format Informasi Berdasarkan Sifatnya

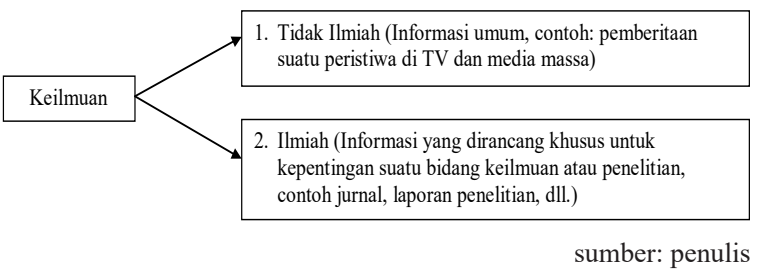

Gambar 2. Ragam/Format Informasi Berdasarkan Keilmuan

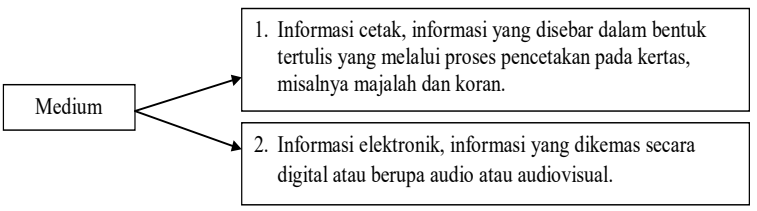

sumber: penulis

Gambar 3. Ragam/Format Informasi Berdasarkan Mediumnya

Sebagai tambahan, Undang Undang Informasi dan Transaksi Elektronik (UU ITE) No. 11 Tahun 2008 mendefinisikan informasi elektronik sebagai berikut.

"satu atau sekumpulan data elektronik, termasuk tetapi tidak terbatas pada tulisan, suara, gambar, peta, rancangan, foto, electronic data interchange (EDI), surat elektronik (electronic mail), telegram, teleks, telecopy atau sejenisnya, huruf, tanda, angka, Kode Akses, simbol, atau perforasi yang telah diolah yang memiliki arti atau dapat dipahami oleh orang yang mampu memahaminya" (UU ITE, 2008).

Dengan pemberian materi ragam kemasan/ format informasi tersebut diharapkan siswa dapat mengenali berbagai macam informasi yang tersedia dengan melimpah ruah di dalam internet. Selanjutnya, siswa dapat menggunakan informasi yang relevan guna mengambil keputusan yang benar dan tepat. Sederhananya, siswa dapat mengambil dan menggunakan informasi yang berasal dari sumber yang dapat dipercaya (trusworthy).

Materi kedua yang diberikan yaitu tentang pengenalan literasi digital-media sosial. Mula-mula siswa dikenalkan pada literasi digital-media sosial, yaitu kemampuan yang dimiliki oleh seseorang untuk memahami, menganalisis, dan mendekonstruksi pencitraan media (Yusuf (2018) dalam Erwina dan Rezeki (2018). Lebih mudahnya, para siswa diberi penyadaran bahwa media sosial itu memiliki tujuan dan kepentingan yang belum tentu sama dengan pembacanya (jika itu berupa tulisan; artikel atau berita) dan penontonnya (jika itu berupa video). 
Dengan kata lain, siswa dikenalkan pada kemampuan untuk mengkonstruksi pesan yang terkadang salah namun seringkali dianggap benar (semua). Dengan demikian siswa menjadi sadarakanmakna/pesan pada media yang diaksesnya sehingga atas kesadarannya tersebut, mereka menjadi lebih bijaksana sebelum membagikan pesan yang didapatkannya tersebut. Pada hal ini, siswa ditekankan untuk terlebih dahulu membudayakan saring sebelum sharing, yaitu menyaring informasi yang didapatkan, mengecek kebenarannya dan memeriksa validasi sumbernya, sebelum pada akhirnya mereka memutuskan untuk membagikannya kepada orang lain.

Pada materi ini juga siswa dibekali pengetahuan dan wawasan akan sisi positif dan negatif akan hadirnya internet. Sisi positif yang dipaparkan di antaranya yaitu (a) jaringan internet membuat segala sesuatunya dilakukan dengan cepat dan efisien dalam waktu; misalnya berkirim surat saat ini bisa menggunakan surat elektronik (email) yang tentu saja jauh lebih cepat jika dibandingkan dengan dikirim melalui POS, dan (b) menggunakan kekreativitasan diri untuk memanfaatkan internet; misalnya dengan menjadi vlogger, membagikan informasi tertentu kepada warga internet melalui video yang diunggah melalui platform Youtube yang mampu mendatangkan keuntungan materiil kepada pembuatnya apabila video yang diunggahnya tersebut ditonton dan dibagikan kepada banyak orang, serta jika banyak orang yang menjadi pengikut setia akunnya. Adapun sisi negatif yang tak luput untuk dijelaskan di antaranya, berupa (1) efek kencanduan internet yang dapat merugikan diri karena membuang waktu dengan sia-sia karena yang diakses bukan merupakan sesuatu yang mendatangkan keuntungan, (2) waspada akan konten negatif misalnya video tak senonoh, (3) waspada cybercrime, misalnya penipuan secara online ketika membeli suatu barang, atau pedofil online yang mengintai anak-anak dari foto-foto yang diunggah ke platform media sosial tertentu, dan (4) bahaya radikalisme.

Selanjutnya siswa juga dibekali dengan materi cara mengidentifikasi berita hoaks. Berdasarkan hasil pengamatan peneliti terhadap sampel berita-berita hoaks yang ditemukan disebarkan melalui media sosial, berita hoaks memiliki ciri-ciri sebagai berikut.

a. Diawali dengan kata-kata yang sugestif(cenderung mengundang kehebohan)

b. Ditulis dengan menggunakan huruf kapital dan tanda seru yang banyak

c. Mencatut nama orang/lembaga terkenal; misalnya tokoh masyarakat, artis, dan lembaga negara

d. Seringkali terdengar mustahil terjadi

e. Tidak muncul di media massa yang bereputasi atau yang tercatat secara resmi di dewanpers. or.id
Pada akhir sesi materi kedua, siswa juga diberikan pengetahuan tentang Undang Undang Informasi dan Transaksi Elektronik (UU ITE) No. 11 Tahun 2008. Pengetahuan tersebut diharapkan dapat menjadi batasan bagi siswa dalam menggunakan internet, agar tidak merugikan orang lain atau melakukan kelalaian sehingga terjerat kasus hukum.

\section{Pengetahuan Siswa Terhadap Literasi Informasi dan Literasi Digital-Media Sosial}

Sebelum mendapatkan kedua materi yang sudah dijabarkan di atas, para siswa terlebih dahulu disurvei akan pengetahuannya tentang literasi informasi dan literasi digital-media sosial, dengan hasil sebagai berikut.

Tabel 1. Pengetahuan siswa terhadap literasi informasi

\begin{tabular}{|c|c|c|c|c|c|c|}
\hline \multirow{3}{*}{ No. } & \multirow{3}{*}{ Sekolah } & \multirow{3}{*}{$\begin{array}{l}\text { Jumlah } \\
\text { Siswa }\end{array}$} & \multicolumn{4}{|c|}{$\begin{array}{c}\text { Variabel: } \\
\text { Mengetahui literasi informasi }\end{array}$} \\
\hline & & & \multicolumn{2}{|c|}{ Sudah } & \multicolumn{2}{|c|}{ Belum } \\
\hline & & & $f$ & $\%$ & $\mathrm{f}$ & $\%$ \\
\hline 1 & $\begin{array}{l}\text { SMAN } 1 \\
\text { Palimanan }\end{array}$ & 36 & 25 & 69,4 & 11 & 30,6 \\
\hline 2 & $\begin{array}{l}\text { SMK } \\
\text { Dinamika } \\
\text { Arjawinangun }\end{array}$ & 89 & 17 & 19,1 & 72 & 80,9 \\
\hline 3 & $\begin{array}{l}\text { SMAN } 1 \\
\text { Cirebon }\end{array}$ & 46 & 46 & 100 & - & - \\
\hline
\end{tabular}

Berdasarkan tabel 1, diketahui bahwa dari 36 siswa sebagai responden di SMAN 1 Palimanan, sebagian besar siswa belum mengetahui apa itu literasi informasi. Selanjutnya dari 89 siswa sebagai responden, sebanyak 72 siswa masih belum mengetahui apa itu literasi informasi dan angka tersebut tergolong tinggi, paling tinggi jika dibandingkan dengan dua sekolah lainnya. Sementara siswa SMAN 1 Cirebon sudah dapat dikategorikan melek informasi mengingat semua responden sudah mengetahui apa itu literasi informasi.

Tabel 2. Pengetahuan siswa terhadap literasi digital-media sosial

\begin{tabular}{|c|c|c|c|c|c|c|}
\hline \multirow[t]{3}{*}{ No. } & \multirow[t]{3}{*}{ Sekolah } & \multirow{3}{*}{$\begin{array}{c}\text { Jumlah } \\
\text { Siswa }\end{array}$} & \multicolumn{4}{|c|}{$\begin{array}{c}\text { Variabel: } \\
\text { Mengetahui literasi } \\
\text { digital-media sosial }\end{array}$} \\
\hline & & & \multicolumn{2}{|c|}{ Sudah } & \multicolumn{2}{|c|}{ Belum } \\
\hline & & & $\mathrm{f}$ & $\%$ & $\mathrm{f}$ & $\%$ \\
\hline 1 & $\begin{array}{l}\text { SMAN } 1 \\
\text { Palimanan }\end{array}$ & 36 & 28 & 77,8 & 8 & 22,2 \\
\hline 2 & $\begin{array}{l}\text { SMK } \\
\text { Dinamika } \\
\text { Arjawinangun }\end{array}$ & 89 & 5 & 5,6 & 84 & 94,4 \\
\hline 3 & $\begin{array}{l}\text { SMAN } 1 \\
\text { Cirebon }\end{array}$ & 46 & 42 & 91,3 & 4 & 8,7 \\
\hline
\end{tabular}

Tabel tersebut menjelaskan sebagaian besar siswa di SMAN 1 Palimanan dan SMAN 1 Cirebon sudah mengetahui apa itu literasi digital-media sosial. Hasil berbeda justru terlihat di SMK Dinamika Arjawinangun yang sebagian besar siswanya masih belum mengetahui literasi digital-media sosial dan 
menunjukkan bahwa siswanya cenderung belum melek informasi digital.

Tabel 3. Pengetahuan siswa terhadap penggunaan internet

\begin{tabular}{|c|c|c|c|c|c|c|}
\hline \multirow[t]{3}{*}{ No. } & \multirow[t]{3}{*}{ Sekolah } & \multirow[t]{3}{*}{$\begin{array}{l}\text { Jumlah } \\
\text { Siswa }\end{array}$} & \multicolumn{4}{|c|}{$\begin{array}{c}\text { Variabel: } \\
\text { Mengetahui penggunaan } \\
\text { internet dengan baik dan } \\
\text { benar }\end{array}$} \\
\hline & & & \multicolumn{2}{|c|}{ Sudah } & \multicolumn{2}{|c|}{ Belum } \\
\hline & & & $\mathrm{f}$ & $\%$ & $\mathrm{f}$ & $\%$ \\
\hline 1 & $\begin{array}{l}\text { SMAN } 1 \\
\text { Palimanan }\end{array}$ & 36 & 29 & 80,6 & 7 & 19,4 \\
\hline 2 & $\begin{array}{l}\text { SMK } \\
\text { Dinamika } \\
\text { Arjawinangun }\end{array}$ & 89 & 68 & 76,4 & 21 & 23,6 \\
\hline 3 & $\begin{array}{l}\text { SMAN } 1 \\
\text { Cirebon }\end{array}$ & 46 & 44 & 95,7 & 2 & 4,3 \\
\hline
\end{tabular}

Hasil tabel 3, menunjukkan bahwa sebagian besar siswa di tiga sekolah telah mengetahui bagaimana penggunaan internet dengan baik dan benar. Secara keseluruhan, siswa sudah dapat mengakses internet dan menelusur lokasi sumber informasi dan media dengan tepat sebagaimana kebutuhan, hanya masih ada beberapa siswa yang belum memahami hal tersebut.

Tabel 4. Pengetahuan siswa terhadap penggunaan media sosial

\begin{tabular}{|c|c|c|c|c|c|c|}
\hline \multirow[t]{3}{*}{ No. } & \multirow[t]{3}{*}{ Sekolah } & \multirow[t]{3}{*}{$\begin{array}{c}\text { Jumlah } \\
\text { Siswa }\end{array}$} & \multicolumn{4}{|c|}{$\begin{array}{c}\text { Variabel: } \\
\text { Mengetahui penggunaan } \\
\text { media sosial dengan baik dan } \\
\text { benar }\end{array}$} \\
\hline & & & \multicolumn{2}{|c|}{ Sudah } & \multicolumn{2}{|c|}{ Belum } \\
\hline & & & $\mathrm{f}$ & $\%$ & $\mathrm{f}$ & $\%$ \\
\hline 1 & $\begin{array}{l}\text { SMAN } 1 \\
\text { Palimanan }\end{array}$ & 36 & 29 & 80,6 & 7 & 19,4 \\
\hline 2 & $\begin{array}{l}\text { SMK } \\
\text { Dinamika } \\
\text { Arjawinangun }\end{array}$ & 89 & 68 & 76,4 & 21 & 23,6 \\
\hline 3 & $\begin{array}{l}\text { SMAN } 1 \\
\text { Cirebon }\end{array}$ & 46 & 44 & 95,7 & 2 & 4,3 \\
\hline
\end{tabular}

Begitu pula dengan hasil survei akan pengetahuan siswa terhadap penggunaan media sosial yang ditunjukkan pada tabel 4 yang menunjukkan bahwa sebagian besar siswa sudah mengetahui penggunaan media sosial dengan baik dan benar, meski pada penelusuran lebih lanjut masih sangat terbatas. Para siswa hanya menggunakan media sosial untuk berkomunikasi dan selebihnya untuk melihat konten yang bersifat informatif dan hiburan.

Tabel 5. Pengetahuan siswa terhadap hoaks

\begin{tabular}{|c|c|c|c|c|c|c|}
\hline \multirow{3}{*}{ No. } & \multirow{3}{*}{ Sekolah } & \multirow{3}{*}{$\begin{array}{l}\text { Jumlah } \\
\text { Siswa }\end{array}$} & \multicolumn{4}{|c|}{$\begin{array}{c}\text { Variabel: } \\
\text { Mengetahui hoaks }\end{array}$} \\
\hline & & & \multicolumn{2}{|c|}{ Sudah } & \multicolumn{2}{|c|}{ Belum } \\
\hline & & & $f$ & $\%$ & $\mathrm{f}$ & $\%$ \\
\hline 1 & $\begin{array}{l}\text { SMAN } 1 \\
\text { Palimanan }\end{array}$ & 36 & 28 & 77,8 & 8 & 22,2 \\
\hline 2 & $\begin{array}{l}\text { SMK } \\
\text { Dinamika } \\
\text { Arjawinangun }\end{array}$ & 89 & 21 & 23,6 & 68 & 76,4 \\
\hline 3 & $\begin{array}{l}\text { SMAN } 1 \\
\text { Cirebon }\end{array}$ & 46 & 46 & 100 & - & - \\
\hline
\end{tabular}

Tabel 5 menunjukkan bahwa siswa di SMAN 1 Palimanan sebagian besar sudah mengetahui hoaks. Hasil survei menunjukkan siswa di SMAN 1 Cirebon secara keseluruhan sudah mengetahui hoaks. Berbanding terbalik, siswa di SMK Dinamika Arjawinangun justru sebagian besar belum mengetahui atau mengenali hoaks.

Tabel 6. Pengetahuan siswa terhadap ciri-ciri berita hoaks

\begin{tabular}{|c|l|c|c|c|c|c|}
\hline \multirow{2}{*}{ No. } & \multirow{2}{*}{ Sekolah } & \multirow{2}{*}{$\begin{array}{c}\text { Jumlah } \\
\text { Siswa }\end{array}$} & \multicolumn{4}{|c|}{ Variabel: } \\
\cline { 4 - 7 } & & & \multicolumn{2}{|c|}{ Sudah } & \multicolumn{2}{|c|}{ Belum } \\
\cline { 4 - 7 } & & $\mathrm{f}$ & $\%$ & $\mathrm{f}$ & $\%$ \\
\hline 1 & $\begin{array}{l}\text { SMAN 1 } \\
\text { Palimanan }\end{array}$ & 36 & 7 & 19,4 & 29 & 80,6 \\
\hline 2 & $\begin{array}{l}\text { SMK Dinamika } \\
\text { Arjawinangun }\end{array}$ & 89 & 11 & 12,4 & 78 & 87,6 \\
\hline 3 & $\begin{array}{l}\text { SMAN 1 } \\
\text { Cirebon }\end{array}$ & 46 & 15 & 32,6 & 31 & 67,4 \\
\hline
\end{tabular}

Selanjutnya, tabel 6 menunjukkan bahwa siswa di tiga sekolah sebagian besar belum mengetahui ciriciri hoaks. Hasil survei menunjukkan siswa SMK Dinamika Arjawinangun memiliki angka tertinggi siswanya belum dapat mengenali ciri-ciri hoaks.

Tabel 7. Kepemilikan siswa terhadap akun media sosial

\begin{tabular}{|c|c|c|c|c|c|c|}
\hline \multirow{3}{*}{ No. } & \multirow{3}{*}{ Sekolah } & \multirow{3}{*}{$\begin{array}{c}\text { Jumlah } \\
\text { Siswa }\end{array}$} & \multicolumn{4}{|c|}{$\begin{array}{c}\text { Variabel: } \\
\text { Memiliki akun media sosial }\end{array}$} \\
\hline & & & \multicolumn{2}{|c|}{ Ya } & \multicolumn{2}{|c|}{ Tidak } \\
\hline & & & $f$ & $\%$ & $\mathrm{f}$ & $\%$ \\
\hline 1 & $\begin{array}{l}\text { SMAN } 1 \\
\text { Palimanan }\end{array}$ & 36 & 36 & 100 & - & - \\
\hline 2 & $\begin{array}{l}\text { SMK Dinamika } \\
\text { Arjawinangun }\end{array}$ & 89 & 89 & 100 & - & - \\
\hline 3 & $\begin{array}{l}\text { SMAN } 1 \\
\text { Cirebon }\end{array}$ & 46 & 46 & 100 & - & - \\
\hline
\end{tabular}

Berdasarkan tabel 7, siswa pada ketiga sekolah tercatat secara keseluruhan sudah memiliki akun media sosial. Adapun akun media sosial tersebut beragam jenisnya, di antaranya Facebook, Instagram, dan Twitter. Semua siswa terdata memiliki akun surat elektronik (email). Hal tersebut dipicu karena untuk kebutuhan mengakses rapor elektronik (e-rapor).

\section{Pengetahuan Siswa Terhadap Hoaks dan Ciri- Cirinya}

Para siswa sebelum mendapatkan materi, terlebih dahulu diberikan ujian awal (pre-test) untuk mengetahui sejauh mana pemahaman mereka terhadap hoaks yang dimunculkan di dalamujian awal tersebut. Hasil ujian awal (selanjutnya digunakan pre-test) diperiksa kemudian dihitung berapa siswa yang menjawab soal ujian dengan benar. Setelah mendapat materi, kemudian mereka diberikan simulasi dan bagaimana memahami hoaks dan berita yang benar. Selanjutnya setelah simulasi diberikan, mereka diberikan kembali ujian akhir (selanjutnya digunakan post-test). Hasil post-test dihitung dan 
dibandingkan dengan hasil pre-test untuk dapat dianalisis dan dideskripsikan. Hasil perhitungan tidak menggunakan perhitungan statistik melainkan menggunakan pendekatan statistik deskriptif dengan data dianalisis secara deskriptif. Adapun hasil pretest dan post-test disajikan dalam tabel berikut ini.

Tabel 8. Kemampuan siswa mengenali hoaks (pre-test)

\begin{tabular}{llccccc}
\hline & & \multicolumn{5}{c}{ Variabel: } \\
No. Sekolah & $\begin{array}{c}\text { Jumlah } \\
\text { Siswa }\end{array}$ & & \multicolumn{3}{c}{$\begin{array}{c}\text { Jawaban } \\
\text { Benar }\end{array}$} & \multicolumn{3}{c}{ Jawaban Salah } \\
\cline { 3 - 7 } & & & $\mathrm{f}$ & $\%$ & $\mathrm{f}$ & $\%$ \\
\hline 1 & $\begin{array}{l}\text { SMAN 1 } \\
\text { Palimanan }\end{array}$ & 36 & 10 & 28 & 26 & 72 \\
2 & $\begin{array}{l}\text { SMK } \\
\text { Dinamika } \\
\text { Arjawinangun } \\
\text { SMAN 1 }\end{array}$ & 89 & 8 & 9 & 81 & 91 \\
& & & & & & \\
Cirebon & 46 & 24 & 52,2 & 25 & 47,8 \\
\hline
\end{tabular}

Tabel 8 menunjukkan bahwa siswa di ketiga sekolah sebagian besar belum mengetahui dan mengenali unggahan yang berkonten hoaks. Data menunjukkan siswa SMAN 1 Cirebon sudah memiliki kemampuan mengenali hoaks meski masih tergolong sedang. Sementara siswa di SMK Dinamika Arjawinangun tergolong tinggi.

Tabel 9. Kemampuan siswa mengenali hoaks (post-test)

\begin{tabular}{|c|c|c|c|c|c|c|}
\hline \multirow{3}{*}{ No. } & \multirow{3}{*}{ Sekolah } & \multirow{3}{*}{$\begin{array}{l}\text { Jumlah } \\
\text { Siswa }\end{array}$} & \multicolumn{4}{|c|}{$\begin{array}{c}\text { Variabel: } \\
\text { Hoaks atau Bukan }\end{array}$} \\
\hline & & & \multicolumn{2}{|c|}{$\begin{array}{c}\text { Jawaban } \\
\text { Benar }\end{array}$} & \multicolumn{2}{|c|}{$\begin{array}{c}\text { Jawaban } \\
\text { Salah } \\
\end{array}$} \\
\hline & & & $\bar{f}$ & $\%$ & $\mathrm{f}$ & $\%$ \\
\hline 1 & $\begin{array}{l}\text { SMAN } 1 \\
\text { Palimanan }\end{array}$ & 36 & 32 & 88,9 & 4 & 11,1 \\
\hline 2 & $\begin{array}{l}\text { SMK Dinamika } \\
\text { Arjawinangun }\end{array}$ & 89 & 69 & 77,5 & 20 & 22,5 \\
\hline 3 & $\begin{array}{l}\text { SMAN } 1 \\
\text { Cirebon }\end{array}$ & 46 & 44 & 95,6 & 2 & 4,4 \\
\hline
\end{tabular}

Setelah diberikan materi tentang pengenalan hoaks dan ciri-cirinya serta simulasi, hasil posttest yang menguji kemampuan siswa dalam mengenali hoaks menunjukkan hasil yang positif, berupa peningkatan angka persentase jumlah siswa yang menjawab tes dengan benar. Ini sekaligus membuktikan bahwa setelah diberi pemahaman, siswa menjadi mengenali hoaks dan juga ciri-cirinya.

\section{Pembekalan Bagi Para Siswa dalam Meng- gunakan Media Sosial}

Tahap terakhir edukasi penggunaan media sosial di kalangan siswa di SMA/sederajat di wilayah Cirebon ini yaitu dengan membekali mereka agar dapat menggunakan internet dan fiturfitur di dalamnya dengan baik dan benar dan agar tidak termakan berita bohong atau hoaks. Kami juga membekali para siswa agar menerapkan prinsip Think before posting! Artinya agar mereka memikirkan kembali dengan matang apa-apa yang akan mereka unggah ke masing-masing akun media sosialnya, karena setelah terunggah maka unggahan itu akan tersebar, dan sekali tersebar, maka unggahan tersebut tidak dapat ditarik kembali atau dihapus. Kami juga menegaskan kepada mereka agar selalu melakukan verifikasi berita/informasi yang didapat sebelum dibagikan kepada orang lain yaitu dengan selalu mengingat SARING before SHARING!

Adapun cara mengindentifkasi suatu berita/ informasi tergolong hoaks atau bukan dapat dilakukan dengan cara berikut ini.

a. Verifikasi kanal berita (dalam hal ini portal berita onlinel situs berita dalam jaringan), apakah dikeluarkan oleh portal berita yang sudah terdaftar atau tidak di www.dewanpers.or.id. Berita hoaks tidak akan diterbitkan oleh portal berita resmi.

b. Verifikasi sumber berita (di antaranya narasumber). Cek pada berita tersebut apakah ada kutipan langsung atau opini dari seorang narasumber. Kemudian cek berita yang memuat konfirmasi dari narasumber yang bersangkutan, apakah benar pernah mengeluarkan pernyataan sebagaimana yang diberitakan di laman hoaks. Ini wajib ditelusuri apalagi bila isunya sensitif.

c. Cek elemen berita/artikel, di antaranya tanggal dan lokasinya, siapa editornya. Karakter berita hoaks tidak jelas tanggal data atau kapan berita itu diterbitkan, dan seringkali tidak memiliki editor.

\section{SIMPULAN}

Hasil studi di lapangan menunjukan fenomena yang sangat ironis, dimana para siswa tercatat $100 \%$ memiliki akun media sosial, namun sebagian besar dari siswa belum mengetahui apa itu literasi informasi dan literasi digital-sosial media. Akan tetapi, hasil dari pemberian materi literasi informasi dan literasi digital-media sosial dapat memberikan dampak positif terhadap pemahaman siswa terhadap penggunaan media sosial yang baik, benar, tepat, dan efektif. Hal tersbut ditunjukkan dengan kenaikan angka persentasi pemahaman siswa terhadap hoaks dan ciri-cirinya pada post-test. Dengan demikian, kami optimis bila program edukasi penggunaan media sosial ini dapat menjadi salah satu alternatif untuk melindungi siswa dari ancaman terpaan konten-konten dalam internet yang berpotensi menimbulkan disintegrasi bangsa. Hal inilah yang mendasari tim kami untuk dapat mengembangkan sayap memberikan pembelajaran literasi informasi dan literasi media tidak hanya di kota Cirebon tetapi juga di beberapa kota atau wilayah lain. 


\section{UCAPAN TERIMAKASIH}

Ucapan terima kasih kami haturkan kepada Universitas Padjadjaran yang telah mempercayai kami sebagai penerima Hibah Penelitian Internal Universitas Padjadjaran Skema Riset Fundamental Unpad (RFU) yang berjudul "Manusia dan Teknologi: Bahasa Sosial Media sebagai Identitas Masyarakat". Dengan demikian, Program Pengabdian Kepada Masyarakat (PKM) dapat kami laksanakan dengan baik, sampai pada akhirnya menghasilkan luaran berupa Jurnal Pengabdian Kepada Masyarakat ini.

\section{DAFTAR PUSTAKA}

Erwina, Wina \& Rejeki, Diah Sri. 2018. Book Chapter: Literasi Informasi dan Media. Bandung: Bitread Publishing.
Indonesia Mendidik. 2016. Kulwap: Melek Literasi di Era Digital. Diakses tanggal 20 Desember 2018, dari laman http://indonesiamendidik. com/tag/anti-hoax.

Republik Indonesia. 2008. Undang-Undang No. 19 Tahun 2016 tentang Informasi dan Transaksi Elektronik. Lembaran Negara RI Nomor 5952. Sekretariat Negara. Jakarta.

2019. Kamus Merriam-Webster dalam jaringan, diakses tanggal 11 Januari 2019, dari laman https://www.merriam-webster.com/ dictionary/hoax.

2019. Kamus Besar Bahasa Indonesia dalam jaringan, diakses tanggal 11 Januari 2019, dari laman https:/kbbi.kemdikbud.go.id/entri/ hoaks 